\title{
Leadership as the effective tool in the organizational management system
}

\author{
Olga Naumova \\ Volga Region State University of Service \\ Gagarina St., 4, 445017 Togliatti \\ Russian Federation \\ e-mail: nikolaevanadezhda87@ mail.ru \\ Nadezhda Nikolaeva \\ Department of Management \\ Volga Region State University of Service \\ Gagarina St., 4, 445017 Togliatti \\ Russian Federation \\ e-mail: nikolaevanadezhda87@ mail.ru
}

\author{
Anna Sherstobitova \\ Department of magistracy (economic and management programs) \\ Togliatti State University \\ Belorusskaya St., 14, 445020 Togliatti \\ Russian Federation \\ e-mail: prof.glv@yandex.ru
}

\begin{abstract}
There are constant complications in the structure of the organization and activity of people during historical developments of society. The similar movement is carried out in the form which represents the formation of new kinds of activity and their allocation as a result of division of the social activities accompanied with growth of its productive force. The history of all human societies was subordinated to the purposes of survival of the certain individual and social community. People live and work in common, therefore their activity due to its public character needs to be managed for giving purposeful implementation and to achieve a final result. The management mechanism of primitive community consisting of the elders, the leader, council and some other institutes of management and influence (divine laws, customs, traditions, rituals) is much simpler than the management mechanism of a modern society. The structure and functions of the modern state are incomparable on complexity with management mechanisms of primitive tribes. The most widespread interactions - between the heads and their subordinates assume hierarchy of the official statuses and promote formation of leadership in the administrative relations. Nowadays the heads have to possess not only professional characteristics but also many personal qualities which promote an effective management. One of such qualities is leadership. This paper contemplates on the leadership as the effective tool of in managing complex organizational systems.
\end{abstract}

\section{Introduction}

The administrative relations which are formed in the process of implementation of any activity are implemented through the management as a type of social activity. The efficiency of the administrative relations depends on their scientific background because of their formation and development under the influence of regularities of management. The purposes fixed in strategic approach to management act as the predominating engine of realization of the administrative relations.

The approaches and definitions displaying a variety of the relation to the management are considered in economic literature. Taylor (1911), the founder of scientific management school, considered that "management as art and the science which knows precisely what should be made and how to make it in the best and cheap way". According to Druker (2003) "management is a special kind of activity turning unorganized crowd into effective purposeful and productive group".

The only pointed out circumstance is that the object of management are the administrative processes happening in territorial, professional and other groups of people who provide the process of production and reproduction of the person, i.e. the administrative relationship (Host'ovecký and Poláčik 2016; or Kubeš and Rančák 2018). In structure of any group focused on performance of any task there is a specific social phenomenon - management that, in turn, leads to the appearance of the individuals or groups who are specially 
engaged in administrative activity (Masiulevičius and Lakis 2018). The administrative relations act as the system of interrelations between subjects of management:

- $\quad$ interest of one subject in a certain functioning of other subject (on the basis of the developed teams);

- interest of the second subject to behave according to management teams of the first for achievement of the purposes, maintenance of effective functioning, development, etc.

In the management system a variety of the relations can be presented in the following form:

1. subordination (implementation of commands, orders);

2. coordination (coordination, contractual relations);

3. external relations and interaction of control systems;

4. internal communications (in the process of management system);

5. simple and difficult (on number of organizational communications between subjects and object of the management);

6. constant and temporary (on lifetime).

It should be noted some specific features of the administrative relations:

- administrative relations at the same time carry subjective (always human relations) and objective character (depend on the level of development of production relations in the society and the sphere where there is a management);

- administrative relations include not only the relations "top management - subordination", but also the whole complex of relationship. Afanasyev (1980) refers to the administrative relations all complex of interrelations between subjects of all kinds of activity concerning management of this activity.

Usually 4 types of the administrative relations are pointed out in economic literature:

- relations between the head and subordinate;

- relations between the head of the management (various levels of spheres);

- relations between subordinates of the management (self-government, the brigade organization of work);

- relations between the head and external environment.

\section{A role of the leader in the administrative relations}

During studying the problem of leadership the scientists suggest a lot of various definitions of this concept.

Table 1. "Leadership" as an utterance definition

\begin{tabular}{|l|l|}
\hline \multicolumn{1}{|c|}{ Author } & \multicolumn{1}{|c|}{ Utterance definition } \\
\hline Terry (1990) & $\begin{array}{l}\text { Leadership is the impact on people groups inducing them to achieve } \\
\text { a common goal }\end{array}$ \\
\hline Tannenbaum et al. (1961) & $\begin{array}{l}\text { Leadership is the interpersonal interaction shown in a certain } \\
\text { situation within a communication process and directed to } \\
\text { achievement of the specific purpose or the purposes }\end{array}$ \\
\hline Koontz and O'Donnell (1980) & $\begin{array}{l}\text { Leadership is connected with an impact on people followed an } \\
\text { achievement of a common goal }\end{array}$ \\
\hline
\end{tabular}

Source: Ladanov (1995)

On the one hand, the leadership is considered as an existence of certain quality sets attributed to those people who successfully influence or interact on others, on the other hand, the leadership is a process of mainly non- power influence in the direction of goal achievement by the group or the organization (Burns 1978; Davies et al. 2001). The leadership represents a specific type of administrative interaction based on the most effective combination of various sources of the power and directed to people motivation to common goal achievement (Rowold and Schlotz 2009; Thrash 2012; Moskalenko and Yevsieieva 2015).

Power possession in the concrete formal or informal organizations of the most different levels and scale from the state and even group of the states to the government agencies, local government or national and public groups and movements is an indispensable condition of the leadership. The formalized power of the leader (from 
the positions in progress) is fixed by the law (Bryman 2007). The process of influence on people through personal abilities, skills and other resources has the definition of informal leadership (Strielkowski and Chigisheva 2018). But in all cases the leader has a social and psychological, emotional support in society or in groups of people which follow him/her (Bass and Avolio 1994).

The organizations which try to obtain success differ from their oppositions mainly which have more dynamic and effective management (Abrham et al. 2015; or Strielkowski et al. 2016). From the point of view of the owner either the individual (the head) or group (administrative board), or process, i.e. the way of organization management having specific features is meant under the management in modern Russian language. The management and the head are the synonyms of the words the leadership and the leader (Bennett and Anderson 2003).

The leadership as the type of the management relationship differs from actually management and is based mostly on the relations such as "leading follower" than "chief-subordinate". The leader carries out noncompulsory influence. The leadership isn't connected with the possibility of using force, coercion, pressure caused by the situation in the organization (a position, status) or official powers. It assumes an interaction of people and support of the leader by the members of the group in which he is in. Everything listed belongs to the informal leadership. The heads are considered as formal leaders who at the same time can be informal leaders or cannot be. Success in management doesn't compensate a bad leadership.

Leadership develops under evolution laws as well in parallel with development of the organization and society in general. When the enterprise arises, then lives and develops in a pioneer phase, the founder of the company is really its charismatic hero. The leadership of this phase is a necessity, it is shown in jet management through enthusiasm by own example. The strategy of leadership at this stage - is a continuous breakout, "fire suppression and fight for survival".

The opinion that the power and a senior position are the most effective instruments of effective management becomes stronger and very widespread. However, if somebody thinks that it is enough, at least, he is short-sighted. In order that the complex organization effectively carried out the tasks, it is necessary to provide performance of all functions of management. But by analogy with the processes of communication and decisionmaking, the management and the leadership is such kind of activity which penetrates all management system. It is impossible to perform effectively the functions of planning, the organization, the motivation and control if there is no effective management.

On the other hand, to become leaders is not at will of the organization though the opportunities to lead people can be increased by the power delegation as well. The members of the organization know who their head is but the conducted don't always know that they are conducted. At last, leaders' actions aren't limited by the frames of any powers or structures. Very often the head is the leader absolutely without any binding to his or her formal position in hierarchy. As we find out soon, in some situations the subordinates can even lead the seniors on a position. The informal basis is considerably peculiar to the leadership.

In general, the leader relations are distinguished by the fact that the followers recognize the leader as a component of the organization only when he/she proved his/her competence and value. The leader receives the power from the followers as they recognize him as the leader. To support his/her position the leader has to give them an opportunity to satisfy the requirements which can't be reached in a different way. In reply they are satisfied with the leader's dominion and the eminence over them and also give him/her necessary support in achievement of the organizational purposes.

The phenomenon of leadership is presented to the organizations by three mechanisms. In formal structure of the organization leadership is the standard and certain right for the power caused by an official position of the head in rigidly outlined activity framework. In informal structure - this is de-facto recognition (non-recognition) of this right in the business sphere from subordinates that is connected with personal characteristics of the leader occupying both a formal and informal position. In the social and psychological sphere leadership represents manifestation of the informal group leadership focused not on the purposes of the organization.

As at any other type of work the effectiveness and quality of the head depend on many conditions and factors. There are both external conditions and internal factors which structure and dynamics depend on the head. These are his personal characteristics; his status characteristics.

It is possible to understand the dynamic system of qualities and properties which are shown rather constantly as actions in various situations as the identity of the head. In addition, the influence is one of the major factors of impact of the leader on surrounding participants of group. Moreover, the influence is defined as behavior of one individual which makes changes to the behavior, the relations, feelings of another individual. Means of such influence can be in varied forms: a request, the stated ideas, dismissal threat, etc. The richness of the parties, aspects of leadership defines a variety of its typology. The simplest and widespread classification of leadership in the organization is allocation of its three types (sometimes they are called as the leader's roles): 
1. Business leadership. It is for the groups evolving from the production purposes. In its background there are such qualities as high competence, the ability to solve better the other organizational problems, business authority, experience, etc. Business leadership mostly strong influences the managerial effectiveness.

2. Emotional leadership. It evolves in social and psychological groups from human sympathies, attractiveness of interpersonal communication. The emotional leader causes the trust in people, radiates warmth, instills confidence, defuses psychological tensions, creates the atmosphere of psychological comfort.

3. Situational leadership. Strictly speaking, by the nature it can be both business and emotional one. However, its distinctive feature is the instability, temporary limitation, communication only with a certain situation. The situational leader can lead group only in a certain situation, for example at general confusion during the fire.

There are also other classifications of leadership depending on the leader's types. Thence, there are six types (roles) of the leader: the leading organizer (performs function of group integration); the leading initiator (predominates at the solution of new problems, puts forward the ideas); the leading generator of an emotional spirit (dominates in formation of mood of group); the leading erudite (differs in extensiveness of knowledge); a leading standard (is the center of an emotional attraction, corresponds to a role of "star", serves as a sample, an ideal); the leading master, the handyman (the expert in some kind of activity). According to the contents they can be distinguished as following:

- leader-inspirers developing and offering the program of behavior;

- leader-performers, organizers of implementation of already set program;

- leaders who are at the same time both inspirers and organizers.

The researches show that success in management comes to the leaders who have persistence and ability to expect, convince, develop strategy, to communicate with people. It is expected that the leaders have to consider technical, social, political and cultural aspects in activity of the organization as parts of uniform system. They have to be able to connect in such way these parts that the picture receives a sense. Surely, in this case there cannot be the only approach, the variety of approaches is rather necessary. Nevertheless, the leader has to seek to have such abilities as ability to involve in the solution of questions of the subordinates, to provide attention to them, innovation, enterprise, response to needs of people.

\section{Leadership as type of administrative influence}

Concrete means by which one person can influence another can be the most various: from the request stated by whispering on an ear to the knife putting to a throat. In the conditions of the organization, for the enterprise the threat of a penalty, demotion and even dismissal can be such "knife". The idea/ideology also should be considered as the effective instrument of influence of one person on another/others. So, Karl Marx who never had any official powers in one political organization and never personally used such means as the violence, had inadvertent, but indisputable influence on the course of events of the twentieth century. The heads have to exert an impact in such way which is easy for predicting and which leads not just to adoption of this idea but to the action - the actual work necessary for achievement of the organization goals. To make the leadership and influence effective, the head has to develop and exercise the power as a resource.

In addition to formal powers, the head needs the power as he/she depends on people both within the chain of teams and out of it. First, the head needs to develop the power because the heads always depend on some people who aren't subordinated to them, and secondly, because practically nobody in the modern organizations of signs will submit completely a continuous flow of his or her orders only because he or she is a chief. In all organizations achievement of effective functioning requires appropriate application of the power in various divisions of the organization the head depends on the direct administration, subordinates and colleagues. Actually these groups represent a part of the surrounding head of the environment. Without assistance of these people the head can't effectively carry out the functions.

Many heads also directly depend on the people and the organizations which are out of their own organization - the suppliers, customers, competitors regulating their activity of departments and labor unions. In ideal option all these people and forces will cooperate willingly with the head and to provide all necessary for performance of work and achievement of the goals of the organization. Unfortunately, the real world does this work slightly more difficult.

Even in that case when the head has accurately certain powers to direct efforts of subordinates, it is not possible. Sometimes, subordinates could refuse to satisfy the head's request, thereby, nullifying his powers. Modern workers are usually much more qualified and less agree to reconcile to the traditional power, than their predecessors. Even if such problem doesn't arise, the head often depends on people who are not formally subordinated to him. For example, as for information and services, the linear managing director depends more 
and more now on staff administrative staff over which he has no control. In some situations the staff has only consultative powers, and in implementation of the recommendations the bureaucrats depend on linear heads.

This dependence on factors and people who can't be operated directly is the main reason for difficulties which are experienced by the leading staff. However, not only feelings suffer. If the head isn't able to interact effectively with these numerous "uncontrollable" forces, he or she can't perform his/her own work, and it will surely reduce efficiency of both an individual labor contribution and activity of all organization. The power and influence, instruments of leadership, are actually only means which the head has for permission of similar situations.

\section{Conclusions}

A role of the head of the organization should be noted especially who at the same time is the formal leader and effectively operates the subordinates. Her/his goal is to influence others so that they performed the work charged to the organization. In the definitions of leadership in the organization many authors tried to formulate accurately that special component which is brought by the leader.

In general, the leadership relations are distinguished by the fact that the followers recognize the leader as an integral part of the organization only when he/she proved his/her competence and value. The leader gets his/her power from the followers as they recognize him/her as the leader. To maintain its position, the leader should provide them with the opportunity to meet their needs, which can't be achieved in another way. In response, they meet the leadership need to dominate and rise above them, and provide them with the necessary support to achieve organizational goals.

Leader in management is a special type of the social leader to whom certain social and psychological and professional qualities are peculiar. This is the authoritative member of collective possessing the legal or actual power in group or the organization. The leader in the organization performs the following functions:

- $\quad$ statement of the purpose before other participants of joint activity and finding of means for a goal achievement;

- their motivation to a certain type of behavior;

- $\quad$ orientation and co-organization of their efforts to the goal achievement, formation of uniform ways to percept reality and the standards of organizational culture.

Many researches showed that success in management comes to the leaders who have persistence and ability to expect, convince, develop strategy, to communicate with people. It is expected that the leaders have to consider technical, social, political and cultural aspects in activity of the organization as parts of the uniform system. Moreover, they have to be able to connect the pieces of the puzzle, so the puzzle would make sense. Surely, in this case there cannot be the only approach, the variety of approaches is rather necessary. Nevertheless, the leader has to seek to have such abilities as the ability to get involved in the solution of questions of the subordinates, to offer them attention, innovation, entrepreneurial skills, as well as to be able to respond to their most basic needs.

\section{References}

Abrham J, Bilan Y, Krauchenia A, Strielkowski W (2015) Planning horizon in labour supply of Belarusian small $\begin{array}{llll}\text { entrepreneurs. } & \text { Economic } & \text { Research-Ekonomska } & \text { Istrazivanja }\end{array}$ doi:10.1080/1331677x.2015.1084238

Afanasyev VG, Systemacity and society, $1^{\text {st }}$ edn. (Moscow: Politizdat. 1980), 368 p.

Bass BM, Avolio BJ, Improving Organizational Effectiveness through Transformational Leadership, 1 st edn. (Thousand Oaks, CA: Sage Publications, 1994), 238 p.

Bennett N, Anderson L, Rethinking educational leadership, 1st edn. (Sage publications, London; UK, 2003 ), 206 p.

Bryman A (2007) Effective leadership in higher education: A literature review. Studies in Higher Education 32(6):693-710. doi: 10.1080/03075070701685114

Burns JM, Leadership, 1st edn. (New York: Harper Torchbooks. 1978), 530 p. 
Davies J, Hides MT, Casey S (2001) Leadership in higher education. Total Quality Management 12 (7-8): 10251030. doi: 10.1080/09544120120096197

Druker P, Practice of management, (Moscow: Williams Publ. 2003), 398 p.

Host’ovecký M, Poláčik M (2016) Communication skills as the competitive advantage of sellers. Czech Journal of Social Sciences, Business and Economics 5(1):18-26. doi: 10.24984/cjssbe.2016.5.1.2

Kubeš V, Rančák J (2018) Sustainability of organization performance via management techniques. Entrepreneurship and Sustainability Issues 5(4):1031-1042. doi: 10.9770/jesi.2018.5.4(23)

Ladanov ID, Practical Management, $1^{\text {st }}$ edn. (Moscow: Elnik Publ. 1995), 494 p.

Masiulevičius A, Lakis V. (2018) Differentiation of performance materiality in audit based on business needs. Entrepreneurship and Sustainability Issues 6(1): 115-124. doi:10.9770/jesi.2018.6.1(9)

Moskalenko V, Yevsieieva I (2015) Effective leadership conflict management in food technology enterprises. International Economics Letters 4(2):91-102. doi: 10.24984/iel.2015.4.2.4

Rowold J, Schlotz W (2009) Transformational and Transactional Leadership and Followers, Chronic Stress. Leadership Review 9:35-48.

Strielkowski W, Chigisheva O (eds.) Leadership for the Future Sustainable Development of Business and Education, 1st edn. (Springer Proceedings in Business and Economics. Springer, Cham, 2018), 672 p., doi: $10.1007 / 978-3-319-74216-8$

Strielkowski W, Shishkin A, Galanov V (2016) Modern management: beyond traditional managerial practices. Polish Journal of Management Studies 14(2):225-231. doi: 10.17512/pjms.2016.14.2.21

Tannenbaum AS (1961) Control and effectiveness in a voluntary organization. American Journal of Sociology 67:33-46. doi: 10.1086/223048

Taylor FW, Principles of Scientific Management, $1^{\text {st }}$ edn. (New York, NY: Harper \& Brothers. 1911), 104 p.

Thrash A (2012) Leadership in higher education. International Journal of Humanities and Social Science 2(13):1-12. 